\title{
Introduction: The Citadel Symposium on Southern Politics
}

\author{
Scott E. Buchanan and DuBose B. Kapeluck, Guest Editors
}

This special edition contains a collection of four of the best papers presented at the Seventeenth Citadel Symposium on Southern Politics in March 2010. Since 1978, The Citadel has biennially hosted what has become the premier conference dedicated to the study of the politics of the American South. Over the course of the last three decades, the Symposium has attracted well over 400 scholars who have presented research devoted to a better understanding of the politics of the region. The Symposium has led directly to the publication of ten books focused on various aspects of southern politics. Indirectly, a number of other books were influenced by research originally presented at the Symposium. The number of peer-reviewed articles that were initially presented at the Symposium are too numerous to cite here.

Southern politics has changed considerably since the first symposium in 1978. In that time, the South has grown enormously in both population and wealth. The region has shifted from a Democratic stronghold at both national and state levels to an increasingly Republican area. In several states, the Republican Party has become dominant at all levels. In addition to the partisan changes, the region has dramatically changed in the area of race relations. When the Symposium first began, it was barely a decade removed from the profound changes in race relations in the South. Today, the South has become a much more racially diverse area that can no longer be understood through the lens of black and white. Current research has already begun to focus on the growing Hispanic populations in the region and how that will affect politics. This is an area that undoubtedly will continue to expand.

Over the years, the panels and research presented run the gamut of scholarly inquiry. Some, but not all, of the panels over the years have focused on race and culture, institutions, state government, public policy, party politics, partisan realignment, as well as discussions on how the South as a region is changing with each passing year. Over the years, one of the frequent topics of discussion is whether or not the South is losing its distinctiveness as a region. While no one will argue that change has been obviously

SCOTT E. BUCHANAN is the director of The Citadel Symposium on Southern Politics.

DUBOSE B. KAPELUCK is the co-director of The Citadel Symposium on Southern Politics.

The American Review of Politics, Vol. 31, Fall, 2010: 175-178

(c)2010 The American Review of Politics 
occurring, opinions deviate from that point. As V.O. Key would caution us though, we should not look at the South as a monolithic entity. Perhaps, it would be more fitting that some southern states are undergoing greater change than others.

The 2010 Symposium was no different from past meetings in either content or discussion. Panels ranged from studies on public policy to historical trends in the region. One of the favorite topics was understanding the 2008 presidential elections and what factors helped President Obama make in-roads in the South and win Florida, North Carolina, and Virginia. One consensus that emerged was that Obama's victories in these areas were due in large part to a dramatic mobilization of young voters and black voters. However, most presenters were reluctant to proclaim that these three states had dramatically shifted to the Democratic Party. Rather, they have become "purple" in which both parties are equally capable of winning elections. The Republican's sweep of the executive branch in the 2009 Virginia elections stands as testimony of this assertion.

Each Symposium, an invited keynote speaker who has made significant contributions in the subfield addresses the participants. This year, Ronald Keith Gaddie of the University of Oklahoma was our keynote speaker. Dr. Gaddie's most recent book, The Triumph of Voting Rights in the South, was co-authored with another of the Symposium's regular participants, Charles S. Bullock, III of the University of Georgia. Dr. Gaddie's service as the keynote speaker continued a long line of eminent scholars who have given their time and expertise to our understanding of southern politics.

As the South changes and continues to evolve, so the Symposium will as well. While we have many of the "old regulars" who have attended the Symposium since the early days of the event, one of the endearing qualities of the Symposium is that it provides a venue for younger scholars to present research at the conference. In some cases, these younger scholars, many of whom initially present research as graduate students, challenge many longheld assumptions about the region's politics. In the future, we anticipate that trend continuing. The South is changing and with it her politics. To appropriate the title of John Egerton's 1974 book, The Americanization of Dixie: The Southernization of America, we anticipate future symposia will focus on many of these same themes as the South seems to be becoming slightly less distinctive than the rest of the nation.

On four previous occasions, The American Review of Politics has provided an opportunity to publish the best research presented at The Symposium. While there were a number of excellent papers presented at the 2010 meeting, four papers rose to the top. As we sat down to consider papers for inclusion in this special edition, we did not set out with a particular theme in mind. As readers will note, the topics of the research vary from issue 
salience to racial politics to congressional elections to presidential politics. However, implicit in each of them is how the region is undergoing continual change. While the research topics certainly differ, this theme of change is quite appropriate given the discussions that took place at the 2010 Symposium.

The first paper, "Change in Southern Congressional Elections: 20042008," by Charles Prysby and Katherine Watkins focuses on change in recent southern congressional races. This period is critical as the GOP continued to perform quite well in most southern congressional districts in 2004 but lost ground in 2006 to the Democrats who held onto their gains in 2008. The authors find the single largest influence on the elections during this time, was the presidential vote. When the Republicans were strong in 2004, Republican congressional candidates did quite well. Beginning in 2006 and continuing through 2008, Democratic candidates began to perform much better. This is largely due to first "Bush fatigue" and secondly the Obama phenomenon in 2008. This research suggests that the Democrats can expect to face a harsh political environment given President Obama's drop in popularity. Beyond this, Prysby and Watkins argue that short-term partisan popularity is more important in many ways than campaign spending. These findings stand in contrast to other research that suggests money is the most important factor in congressional elections. The findings presented in the paper challenged some long-held assumptions about congressional elections. This research will be even more illuminating as we compare the findings in this paper to how trends emerge in the 2010 midterm elections.

The South has historically been noted for its concern with race. In turn, race has always played a large role in the region's politics. While there is evidence that the role of race may not hold its traditional level of influence, it nonetheless remains. Most scholarly research has focused on the role of white/black relations and in southern politics. Patrick Miller, however, takes the concept of racial threat voting and studies it in the context of the growing Latino population in the South. Testing three different models, Miller uses the traditional threat voting model first posited by V.O. Key in 1949 to the changing diversity of the southern population. In the end, the results suggest that traditional ways of understanding race and ethnicity in the regions may be outdated as the number of Latinos dramatically increases with each passing year.

The third paper in this collection is Michael Bitzer's "In North Carolina, It's Not Election Day-It's Election Month: An Analysis of the 2008 Election." North Carolina is part of a growing trend among states to offer voters the opportunity to cast a vote before Election Day. Within this context, Bitzer's precinct-level analysis is concerned with two separate, though related, issues. First, given the Obama campaign's belief that North Carolina 
could potentially be won, there were extensive mobilization efforts in the state. Did Democratic mobilization translate into meaningful gains among early voters? Second, Bitzer makes the argument that "place matters." Scholars have become increasingly interested in how voting behavior differs across urban, suburban, and rural areas. How did these voters differ in their response to the Obama campaign's mobilization efforts, and was there an interaction apparent in early voter turnout? Bitzer's research suggests that early voters were more likely to cast a ballot for Obama than McCain in 2008. Moreover, this is the case in both urban and suburban precincts. While race and partisanship were powerful predictors of Democratic strength across North Carolina's urban, suburban, and rural precincts, early voting and "place" both exhibit strong independent effects as well. Bitzer's work is an important contribution to the discipline.

Our last paper is an ambitious piece of research by Shannon L. Bridgmon. Bridgmon, in "Intraparty and Interparty Variations of Issue Salience in Southern Parties," focuses on "issue ownership" between the two major parties within the state as well as party differences across the South. This work fills a void in the literature, which has little to say on the subject of sub-national partisan issue salience. She uses a unique data set derived from content analysis of state Democratic and Republican Party platforms to assess the degree to which particular issue areas are salient within a state and the extent to which ownership of these issues are party specific. Her analysis reveals a rich variety of preferences across the southern states, demonstrating empirically that "all politics is local." While Bridgmon confirms our general perceptions of ideological differences between the two major parties, her state-by-state and issue-by-issue breakdown serves to emphasize the complexity of electoral politics at the state level.

We feel these articles help to expand our knowledge in the field of southern politics. While much is changing about the South, it still retains its political distinctiveness as these four scholars have demonstrated in their research. As one studies the South, its complexity and nuances become ever more present. We hope that the readers will find some illumination from these papers. Also, we would like to issue a cordial invitation to attend the next Symposium on Southern Politics scheduled for March 1-2, 2012. 